\title{
The Economic Dimension of A Decision on a Territorial Exchange: Southern Bessarabia for Northern Dobruja
}

\author{
Razvan Stefanescu \\ rstefanescu@,ugal.ro \\ Ramona Dumitriu \\ rdumitriu@,ugal.ro \\ Dunarea de Jos University of Galati, Romania
}

A territorial change could have complex economic consequences for both the country that annexed a province and the country that lost it. This paper approaches the economic aspects of the territorial exchange from 1878, when Romania received the Northern Dobruja as a compensation for losing Southern Bessarabia. The economic potential of Northern Dobruja played a major role in the controversial decision of the Romanian Government to accept, de facto, the territorial exchange.

Keywords: Regional development, Economic values of the territories, Decisions on the territorial exchanges, Counterfactual history.

JEL Codes: N13, N44, R10

\section{Introduction}

The territorial changes are among the most important outcomes of the international conflicts. For the countries involved, the economic consequences are various and complex. The annexation of a territory could bring to a country some significant gains, such as natural resources, industrial entities or access to trade routes. However, some industries or some regions could be affected by the competition from the new territory (Abramson, 2017).

Usually, in order to achieve the public opinion support for the annexation of a territory, the government of a country invokes, along with the economic value of the province, the historical rights and the ethnic composition (Forsberg, 1996; Abramson \& Carter, 2016). All of three factors are marked by ambiguity. The assessment of province economic value could be very complex since it uses many criteria. Sometimes, a government promotes its own subjective version over the historical rights on a disputed territory. Quite often, after a country had annexed a territory, its government tried to change the ethnic composition by colonization which was preceded, sometimes, by ethnic cleansing.

Usually, the annexation of a territory generates, among states, tensions that could last for decades or even centuries. A country which lost a province could try to regain it even by provoking a war. Sometimes, the territorial disputes damage, on a long term, the peace and the commercial relations, not only of the countries involved but also of their neighbors. A special solution for the territorial disputes is the territorial exchange in which the loss of a province is compensated by the gain of another one. In this way the tensions among the countries involved could be eliminated or, at least, attenuated (Kacowicz, 1994; Tir, 2006).

In this paper we approach the economic consequences of a territorial exchange that occurred after the War of 1877-78, in which Russia, allied with Romania, Serbia, Montenegro and Bulgarian insurgents, had defeated Turkey. After the war had ended, Russia annexed three counties of Romania, known as the Southern Bessarabia, and offered, as compensation, the Northern Dobruja, a territory just gained from the Ottoman Empire. At that moment, the public opinion from Romania was very displeased by the former ally's attitude. There were Romanian politicians that asked the government to not accept Northern Dobruja as compensation because, 
in their opinion, that province could bring many troubles and few advantages (Iordachi, 2013). However, the pragmatism prevailed and Romanian authorities accepted, de facto, the territorial exchange. This decision had significant consequences for the economies of the two provinces.

\section{Circumstances of the decision on the territorial exchange}

\subsection{Historical rights on the two provinces}

Before the territorial exchange from 1878 the suzerainty over the two provinces passed to different countries. In these circumstances, the historical rights over them are still controversial subjects among the historians and politicians (Markof, 1916; Bratianu, 1995).

During the first century A D, the territories of the two provinces became parts of the Roman Empire which had gradually conquered them from the tribes of the populations such as Dacians, Sarmats, Sciths or Bastarnae. When the Roman Empire was divided in 395 A D, the territories of the two provinces were attributed to the Byzantine (East Roman) Empire. From the fourth to the thirteen century A D the passage of several migratory populations (Huns, Avars, Slavs, Bulgars, Magyars, Pechenegs, Cumans etc.) challenged the Byzantine suzerainty. In the seventh century, First Bulgarian Empire extended its authority, with intermittences, over Northern Dobruja and Southern Bessarabia. In the tenth century the decline of First Bulgarian Empire allowed the Byzantines to reestablish their control over most of Northern Dobruja territory. Meanwhile the Pechenegs and, later, the Cumans conquered parts of Southern Bessarabia and Northern Dobruja. At the end of the twelfth century Second Bulgarian Empire controlled most of Northern Dobruja territory.

In 1241 the Mongols (Tatars) conquered Southern Bessarabia from the Cumans and they controlled a part of Northern Dobruja. This territory was later incorporated in the territory ruled by the Golden Horde (according to some sources, at the beginning of the fourteenth century, Toqta, the Khan of the Golden Horde gave Southern Bessarabia to the Bulgarian Emperor Theodore Svetoslav). In these times the Mongols allowed Genoese merchants to establish some colonies on the shores of Danube and Black Sea they controlled.

At the middle of the fourteenth century, the Golden Horde decline brought significant changes for Northern Dobruja and Southern Bessarabia. In that period, a new state, possibly detached from the Golden Horde, led by the Tatar prince Demetrius, controlled the river mouths of Danube. Another state, led by the despot Dobrotitsa (he gave his name to the future province Dobruja) gradually extended its authority from the Danube Delta to Messembria.

There were not yet elucidated the circumstances of Southern Bessarabia detachment from the Golden Horde (Iorga, 1899; Boldur, 1992; Chirtoaga, 2004). A controversial thesis claimed that in the fourteenth century the province came, for a while, under the authority of Wallachia principality (Nistor, 1991; Turcanu, 2009). However, at the beginning of the fifteenth century or even earlier, it became a part of the principality of Moldavia (Iorga, 1899; Turcanu, 2011).

In the second half of the fourteenth century, the expansion of the Ottoman Empire in the East of Europe has threatened Wallachia, Moldavia and the state led by the followers of Dobrotitsa. In 1388, a Turkish expedition conquered most of Northern Dobruja. The prince of Walachia, Mircea the Elder, reacted with a military campaign that expelled the Ottoman Army. In the next years, Dobruja became a battlefield where Wallachia, allied with the Kingdom of Hungary, fought against the Ottomans. In 1402, at Ankara, in a dramatic battle, the Mongol Khan Timur Lenk defeated and captured the Ottoman sultan Bayezid I. Mircea the Elder took advantage from the civil war that followed in the Ottoman Empire, occupying parts of Dobruja. However, in 1420, Mehmed I, the new Ottoman sultan, conquered Dobruja which remained an Ottoman province for more than four centuries.

In the next decades, while the Turkish pressure intensified, Moldavia and Walachia had to pay tribute and to accept a form of vassalage to the Ottoman Empire. Moreover, they had their territories amputated by the powerful neighbor. In 1484 the Turks conquered from Moldavia two strategic fortresses and ports: Chilia and Moncastro (Cetatea Alba). Later, in 1538, the sultan 
Suleiman I took Tighina (Bender), another important fortress of Moldavia. In the next decades, the Turks allowed the semi-nomad population of Nogai-Tatars to inhabit the territory conquered from Moldavia. That territory was named Budjak or Bessarabia. On the Danube, the Ottomans built the powerful fortress Ismail. Both Bessarabia and Dobruja were included in Silistra Eyalet, an important administrative entity of Turkey.

Beginning with the eighteenth century, Bessarabia and Dobruja were affected by the Ottoman Empire decline and by the expansion of Russia. After a series of Russo-Turkish wars, some of them taking place on the territories of the two provinces, the borders of Russia arrived at the Dniester River, near Bessarabia. A significant number of Muslim inhabitants from the territories lost by Ottomans took refuge in Bessarabia and Dobruja. While remaining, formally, the suzerain of the two principalities, Turkey was forced to accept Russia's growing influence, as a "Protector" of the Christian population from these countries.

After the Russo-Turkish War of 1806-1812, the czar Alexender I annexed almost a half of Moldavia, including Budjak. From these times, the name of Bessarabia was applied to the whole territory gained by Russia. In fact, since Tilsit Treaty obliged Russia to evacuate Moldavia, the czar diplomats deliberately named Bessarabia the territory between the rivers Pruth and Dniester, in order to create a confusion that allowed maintaining the army there. During the first years of war, the Russian Army directed a hard ethnic cleansing against the Tatars from Budjak forcing them to leave their homeland. On the deserted territory there were invited colonists with different nationalities: Bulgarians, Gagauz, Germans, Russians, Moldavians etc. (Boldur, 1992; Ciachir, 1992; Bratianu, 1995). During the life of czar Alexender I, a real autonomy was granted to the new province. However, his successor, the czar Nicholas I, drastically limited that autonomy. In 1829, Russia defeated Turkey in other war and annexed the Danube Delta. This acquisition worried the other major European Powers, especially Great Britain, since it offered to Russia the control over an important commercial route.

In 1853, Great Britain and France sent their armies to protect the integrity of Ottoman Empire which was again attacked by Russia. In 1855, Sardinia-Piedmont joined the coalition that succeeded in defeating Russia the next year. By the Treaty of Paris, signed in March 1856, Great Britain and France imposed to Russia hard obligations, meant to remove its control over the Danube Mouths. The Danube Delta was returned to the Ottoman Empire, while three counties (Cahul, Bolgrad and Ismail) from the Southern Bessarabia were offered to Moldavia. The Black Sea was neutralized and Russia had to limit its military fleet and its coastal fortifications. The lower section of the Danube was internationalized and the new established European Commission of the Danube received the authority to control the commerce on that part of the river. The Russian Protectorate over the two Danubian Principalities, Moldavia and Wallachia, was replaced by the guidance of the Great Powers. The French Emperor, Napoleon III, who viewed the two countries as a strategic interest for his policy in the Eastern Europe, acted to strength them by unification. In 1859, with his support, the thrones of Moldavia and Wallachia were occupied by the same person, Alexandru Ioan Cuza. In the next years, the new state, known as United Principalities of Moldavia and Wallachia, Romanian Principalities or, simple, Romania was recognized by the Great Powers.

Prince Cuza implemented radical reforms to modernize the public administration and to stimulate the economy. In 1866 he was deposed being replaced by the prince Carol of Hohenzollern-Sigmaringen. In the next years, after the unification had been consolidated, the main objective for the politics of the new state of Romania was to gain the independence from Turkey.

\subsection{The Oriental Question}

The defeat in the Crimean War led to some reorientations in the Russian foreign policy. The new minister of foreign affairs (later chancellor of the Russian Empire) Alexander Gorchakov, adopted a cautious way to reestablish the country influence in the Balkans and to regain the lost territories. After France had been defeated by Prussia in the war of 1870-71, 
Russia denounced the drastic clauses of the Treaty of Paris that limited its military presence on the Black Sea. In 1873 Russia joined Germany and Austria-Hungary to form the League of the Three Emperors, an alliance that influenced the Eastern Europe for decades.

The emerging of a new Balkan Crisis offered to Russia an opportunity to regain Southern Bessarabia and to increase its influence in the South-East of Europe. In 1875, in Herzegovina, the ethnic Serbs revolted against Ottoman rule. A year after, the Principalities of Serbia and Montenegro declared war on Turkey. The difficulties of the Ottomans in Balkans aggravated when Bulgarians also organized an insurrection against their rule. The Ottoman Army, helped by irregular troops, managed to defeat the insurgents but the atrocities that accompanied the repression outraged the international public opinion, offering to Russia the pretext to start a war against Turkey.

\subsection{Pre-war negotiations on the territorial exchange}

On the war that was to begin, Russian statesmen counted on Germany's support. However, the other member from the Three Emperors League, Austria-Hungary, worried that its own interests in Balkans could be affected. To calm its ally's suspicions, Russia approved, in July 1876, on the Reichstadt Agreement, Austria-Hungary's intention to annex Bosnia. In compensation, Austria-Hungary agreed that Russia could annex Southern Bessarabia and some territories in Caucasus. In the new circumstances, Great Britain remained the main opponent to Russia's actions against Turkey. However, because of the atrocities the Ottoman army had committed, the Prime Minister Disraeli was aware that he couldn't achieve the public opinion support for a military intervention to preserve Turkey's integrity.

On the Russian plans for the future war, the cooperation with Romanian authorities had a major importance since, in its way to Balkans, the Russian army had to pass the Romanian territory. Some important Romanian statesmen viewed the conflict between Russia and Turkey as an opportunity to gain the country's independence. However, there was no secret for them that Russia intended to annex Southern Bessarabia. In these circumstances, among the Romanian politicians there were two factions regarding the position their country had to adopt in the future conflict: one that was favorable to neutrality and the other that wanted a closed cooperation with Russia. In the summer of 1876, a new Government, led by Ion C. Bratianu, was formed in Romania. While the Prime Minister was favorable to the cooperation with Russia, other important members of his cabinet, including the foreign minister Nicolae Ionescu, pledged for neutrality. Benefiting by Prince Carol's support, Bratianu adopted a cautious policy. In the autumn of 1876 he visited Russia, meeting, at Livadia, the Emperor Alexander II and the chancellor Gorchakov. There are two main versions about the secret negotiations during this visit. The first one claims that Romanian Prime Minister tried to find out about Russia's intentions on Southern Bessarabia, but obtained no clear answers from the Emperor or from the chancellor (Bratianu, 1995). According to the second version, Bratianu accepted Northern Dobruja as a compensation for the loss of Southern Bessarabia, but he informed his Russian partners that he needed time to convince the Romanian public opinion to accept this territorial exchange (Jelavich, 1969).

In October 1876 Russia issued an ultimatum to Turkey asking to stop military actions against Serbia and Montenegro. The Ottoman Empire accepted an armistice with the two countries, while the Great European Powers agreed to discuss the situations from revolted provinces of Herzegovina, Bosnia and Bulgaria. Meanwhile, Romanian Prime Minister Bratianu negotiated with the Russian diplomat Alexandr Nelidov a secret agreement about the passage of the Russian Army on the Romanian territory (Nélidow, 1915). At the Constantinople Conference from 1876-77, the Great European Powers asked the Ottoman Empire to grant a large autonomy to Bulgaria, Herzegovina and Bosnia (the province of Bulgaria was supposed to include Northern Dobruja). At the beginning of 1877, Turkey refused to fulfill the conference decisions, arguing that problems of the revolted province would be solved by a new Constitution. With the war becoming imminent, on January 15, 1877, at Budapest, Russia and Austria-Hungary signed a new 
secret agreement, in addition to those from Reichstadt. This convention strengthened the plans for annexation of Southern Bessarabia, by Russia, and of Bosnia and Herzegovina, by AustriaHungary. Russia also promised not to create a large Slavic state that could affect AustriaHungary's interests in Balkans. A second international conference, in March 1877, at London, failed to bring a solution to the Balkan crisis, so the war was unavoidable.

In the spring of 1877, Russia sent in Romania a diplomat, Dmitri Stuart, to sign the convention regarding the passage of the Russian Army on the Romanian territory. When this agreement was presented by Prime Minister Bratianu to the other members of the Romanian Govern, the foreign minister Nicolae Ionescu resigned. He was replaced by Mihail Kogalniceanu, one of the most capable Romanian statesmen and a partisan to the cooperation with Russia. In April, Kogalniceanu signed the convention which mentioned Russia's obligation to preserve Romania's territorial integrity.

\subsection{Post-war negotiations on the territorial exchange}

After Russia declared war to Ottoman Empire and its army entered in the Romanian territory, Turkey adopted retaliation measures, including the bombing of some Romanian towns. These acts outraged the Romanian public opinion, undermining the position of the neutrality's partisans. In these circumstances, the Romanian Parliament proclaimed the state of war with the Ottoman Empire. Some days later, Romania declared its independence but this act wasn't recognized by the Great Powers.

During the negotiations with Russia, Romania proposed that its army could play an active role in the future war. This offer was rejected, because Russian militaries had a poor opinion of the Romanian army's ability to carry a modern war and also because the Russian statesmen feared this could be a moral obstacle to the annexation of Southern Bessarabia. Initially, the tasks Romanian forces had to fulfill were mainly auxiliary on the Russian offensive in Balkans, the main theatre of war. However, the evolution of the war changed this situation. After some initial successes, the Russians suffered major setbacks at the strategic fortress of Plevna. In the new circumstances, Russia negotiated a military alliance with Romania. Under Prince Carol's command, the Romanian forces had a major contribution in the fall of Plevna. After the Ottoman army from Plevna had capitulated, Russians launched a daring winter campaign in Balkans which ended, in January 1878, with the fall of the strategic town of Adrianopole. This advance alarmed Great Britain which sent its fleet into the Sea of Marmora. To avoid a direct confrontation with Great Britain, Russia offered Turkey an armistice that was followed by peace negotiations at San Stefano, a village near Constantinople.

Signed on March $3^{\text {rd }}$ of 1878 , the Treaty of San Stefano was meant to assure a predominant position of Russia in the South-East of Europe. It created a new large Bulgarian state, with access to both Black Sea and Aegean Sea. Although, the new state had a nominal vassalage to Turkey, it was obvious that in fact it was a satellite of Russia and the Russian fleet could use its Mediterranean ports. Turkey had to recognize the independence of Romania, Serbia and Montenegro. Important territorial acquisitions were offered to Serbia and Montenegro, while Romania had to renounce Southern Bessarabia, receiving, as compensation, Northern Dobruja. Russia also annexed some former Ottoman territories from Caucasus.

The forced territorial exchange took by surprise Romanian public opinion which was infuriated by losing Southern Bessarabia. The former partisans of neutrality used this situation to combat the Govern. Romanian authorities strongly protested to Russia against the flagrant violation of the Convention signed in April 1877. As the tension between the two countries aggravated, the Russian militaries threatened to disarm Romanian army.

Finally, the terms of the San Stefano Treaty had to be modified due to the opposition of Great Britain and Austria-Hungary. Prime Minister Disraeli was worried that Russia's dominant position in the South-East of Europe threatened Great Britain communications with India and Persian Gulf. The statesmen from Austria-Hungary viewed the new large Bulgarian state as a violation of Budapest Convention. Exhausted by the war with Turkey, Russia couldn't afford to 
confront with an alliance of the two Great Powers. In order to avoid a European war, German chancellor Bismarck offered his mediation, and the Great European Powers agreed for the organization of a Congress at Berlin. At this Congress, the territory attributed to new Bulgarian state was considerable diminished and Austria-Hungary obtained the right to occupy Bosnia and Herzegovina. However, despite Great Britain's efforts, Russia still acquired Southern Bessarabia. As compensation, Romania obtained the territory of Northern Dobruja (larger than those offered by the Treaty of San Stefano) and the recognition of its independence. The Romanian Government had to accept this solution, but the political opposition continued to warn public opinion about the ethnic problems of Northern Dobruja and about what it was, in its perception, the poor economic value of this territory.

\subsection{Ethnic problems of the two provinces}

After the deportation of the tartars from Budjak, during the war of 1806-12, the territory was repopulated with colonists from Russian Empire and abroad. Among them, there were large communities of Bulgarians that had left their homelands during last Russo Turkish wars. On the county of Bolgrad, the Bulgarian population had the majority. In fact, on the three counties received by Moldavia after the Crimean War, the Romanian population had the smallest proportion from the whole Bessarabia (Bratianu, 1995).

The territory of Northern Dobruja corresponded mainly to Tulcea (Tülca) Sandjak of the Ottoman administration. A pre-war census indicated that more than a half of the families living in this sandjak were Muslims. A considerable part of them were formed by Tatars and Circasians that left Crimea and Caucasus after that provinces had been lost by the Ottoman Empire. There were also significant communities of Romanians, Bulgarians and Russians-Lipovans. Between 1876 and 1878, the revolt of Bulgarians and the war campaigns caused a considerable part of population from Dobruja to leave its homeland.

Like Southern Bessarabia, Northern Dobruja had a complex ethnic composition, being an amalgam of populations. The main difference has a confessional dimension associated to the Muslim majority of the population from Northern Dobruja.

\subsection{Perceptions on the economic values of the two territories}

The economy of Southern Bessarabia was, in 1878, mainly an agricultural one. The region had rich soils, adequate for the grain production. For Romania, the province also had a strategic value since it facilitated, by the Danubian ports of Reni and Ismail, the access to the Black Sea. In general, the infrastructure, especially represented by roads, was in poor conditions. In the period 1856-1877, Romanian authorities, being aware that Russia could regain this territory, made no significant efforts to improve it.

During the Golden Age of the Ottoman Empire, Dobruja benefited by its geographical position, its territory being passed by some important roads from Turkey to Russia, Poland and Danubian Principalities. The decline of the empire led to a decreasing importance of its roads. Moreover, the Russian Turkish wars caused significant destructions in Dobruja. However, in the second half of the nineteenth century, the strategic interest of European countries in the Danube as a trade waterway increased the importance of the province (Ardeleanu, 2008). The internationalization of Danube created opportunities for the region development. However, the navigation on the Danube Mouths had to deal with some technical problems that affected its reliability. In 1857, a British consortium proposed to the Ottoman authorities the building of a railway from the Danubian port Cernavoda to the Black Sea port of Constanta (Kjustendža). This investment, which included the modernization of the two ports, was finalized in 1860, but the profitability of the transport proved to be much lower than it had been expected (Ardeleanu, 2006).

The economy of Northern Dobruja had an important agricultural component. However, in general, its soils were not as rich as those from Southern Bessarabia. 
In the territorial exchange period, the Romanian society was not very well informed about the economic potential of Northern Dobruja. For a conservative society, as the Romanian one was in the nineteenth century, the economic value of a region was assessed mainly based on the suitability for the grain cultivation of its land. In general, Northern Dobruja was perceived in Romania as an arid land, where the grain cultivation couldn't be very efficient.

\section{The economic impact of the territorial exchange}

\subsection{The development of Northern Dobruja after the territorial exchange}

In the years that followed the territorial exchange, the three Romanian statesmen who were perceived as responsible for this act, Prince Carol, Prime Minister Ion C. Bratianu and the foreign minister Mihail Kogalniceanu, were preoccupied by the integration of Northern Dobruja in the economic system of Romania. It was not only a matter of political prestige, but also the vision of the province future role which offered access to the Black Sea. Soon after the gain of Northern Dobruja, important public funds were directed to the infrastructure of this territory. In 1882, Romanian government bought, from the English company Barklay, the railway ConstantaCernavoda (including locomotives and wagons used by this company) paying 16.8 million French francs. In the next years, the railway was extended and modernized. Between 1890 and 1895, a bridge over the Danube River was built at Cernavoda. The cost of the new bridge, which connected Constanta and Bucharest by railway, was about 35 million lei (in those times, "leu", the Romanian national currency, had a parity of 0.32 grams of gold). Romanian authorities also developed the port of Constanta, spending, from 1895 to 1916, about 76 million lei (Lazarovici, 1920). The port capacity increased significantly and Constanta became, at the beginning of the twentieth century, the main outlet for the Romanian foreign trade (Table 1).

Table 1. Imports and exports through the port of Constanța between 1899 and 1905

\begin{tabular}{|c|c|c|}
\hline Year & Imports [tons] & Exports [tons] \\
\hline 1899 & 142,265 & 74,999 \\
\hline 1900 & 60,963 & 119,952 \\
\hline 1901 & 110,434 & 214,901 \\
\hline 1902 & 55,844 & 372,081 \\
\hline 1903 & 56,263 & 401,095 \\
\hline 1904 & 65,597 & 286,018 \\
\hline 1905 & 165,668 & 520,090 \\
\hline 1906 & 96,508 & 731,641 \\
\hline 1907 & 228,850 & 840,656 \\
\hline 1908 & 151,988 & 619,710 \\
\hline 1909 & 89,832 & 694,895 \\
\hline 1910 & 116,254 & 955,655 \\
\hline 1911 & 110,418 & $1,212,978$ \\
\hline 1912 & 162,649 & $1,273,084$ \\
\hline 1913 & 218,950 & $1,323,445$ \\
\hline
\end{tabular}

The structure of exports by the port of Constanta changed in time (Table 2). At the end of the nineteenth century, the Romanian exports consisted mainly in cereals. However, on the international markets, the supply of Romanian cereals had to face an increasing competition, especially from the United States agriculture. Between 1910 and 1914, the exports of cereals experienced a descendant trend. Instead, the port of Constanta benefited from the exploitation of Romanian oil resources. At the beginning of the twentieth century new installations for 
transporting oil were built and, since 1910, the exports of oil products experienced an ascendant trend.

Table 2. Exports of cereals and oil products by the port of Constanta between 1910 and 1913

\begin{tabular}{|c|c|c|c|c|}
\hline Category of goods & $1910-1911$ & $1911-1912$ & $1912-1913$ & $1913-1914$ \\
\hline Cereals and vegetables [tons] & 551,636 & 556,900 & 269,881 & 319,173 \\
\hline $\begin{array}{c}\text { Oil and petroleum products } \\
\text { [tons] }\end{array}$ & 456,386 & 597,750 & 797,822 & 719,454 \\
\hline
\end{tabular}

Source: Lazarovici (1920).

At the end of the nineteenth century an enterprise for the ships' repair was established within Constanta Harbor area. The Romanian authorities encourage the exploitation of the shores near Constanta to tourism purposes. The growing importance of Constanta was reflected in the evolution of the town's population: from about 5000 citizens in 1878 to more than 31000 in 1912.

The efforts to increase the proportion of Romanians in Northern Dobruja's population implied a reorganization of the territory's agriculture. In the 1880s the Ottoman rules over the land's property were replaced by a new legislation which gave to Government the possibility of organizing a large colonization of the province. In the next years, large areas of arable land were attributed to colonists from the other Romanian provinces. The population of Northern Dobruja increased from about 147,000 in 1878 to more than 260,000 in 1900 (Hunt, 2013; Iordachi, 2013). In 1984 it was finalized a navigable canal linking Cernavoda and Constanta. Today, Constanta is the fifth most populous city in Romania.

3.2. Economic consequences for Southern Bessarabia and for the Danubian ports Galati and Braila

After the transfer to Russian Empire, Southern Bessarabia was treated as a marginal province useful mainly for its agriculture. The farms from this province, which had used to export their products through the Romanian ports to the Danube, had to sell them through Odessa, with increased costs. The Danubians ports of Reni and Ismail lost their strategic importance they had within the Romanian administration. In the present, in the territories that belonged to the Southern Bessarabia the economy is still mainly an agricultural one.

The development of Constanta generated a significant competition for the two main Romanian Danubian ports, Braila and Galati. In 1883, the two towns lost their privileges of free ports (it is problematic if in the Romanian Government's decision counted the access to the Black Sea offered by Constanta). In the next decades, the shipping industry proportions in the economies of the two towns significantly decreased.

\section{Conclusions}

From the counterfactual history perspective we could imagine what it would have happened if that territorial exchange hadn't occurred. If Southern Bessarabia had remained a part of Romania, its Danubian ports of Reni and Ismail, together with two other ports of Galati and Braila, would have provided the only access of the country to the Black Sea. This fact would have given them a strategic importance influencing their future economic development. If the Great Powers hadn't attributed Northern Dobruja to Romania, the economy of this region would probably look very different today. It is mostly unlikely that the Bulgarian government would have spent large public funds to develop Constanta since the country had already two excellent ports to Black Sea, Varna and Burgas. Moreover, Bulgaria would have had few reasons to build a navigable canal linking the Danube by the Black Sea. Anyway, such debates are somehow useless since, in 1877-78, Russia could have counted on Germany's and Austria-Hungary's support for the annexation of Southern Bessarabia. Romania couldn't oppose, alone, to Russia's intentions, so its government had no option but to accept. 
Along with the economic development of the region, Romania's strategy regarding the integration of Northern Dobruja had also a demographic component. At the beginning of the twentieth century, the organized colonization and a significant immigration to Turkey of the Muslim habitants led to a Romanian majority in the province (until then, the territory had a special administration and no elections were organized). At the end of the Second Balkan War, in 1913, Romania gained, from the defeated Bulgaria, another part of Dobruja (it was named Southern Dobruja, the New Dobruja or the Cadrilater). The new territory was colonized by Romanians from the other provinces or Aromanians from Balkan countries. In 1916, in the context of the First World War, Bulgarian Army occupied Dobruja.

By the Treaty of Bucharest, in May 1918, Romania had to cede Southern Dobruja and a southern part of Northern Dobruja to Bulgaria. The rest of Northern Dobruja was to be kept, in a condominium, by Germany and Austria-Hungary (these countries realized the strategic position of Constanta and of the Danube Mouths and refused to cede them to the Bulgarian ally). In that moment it seemed that important investments made by Romania in Northern Dobruja were lost. In 1917 the Russian Empire disintegrated. In other territorial exchange, that could be viewed as opposite to those from 1878, the Central Powers allowed Romania to regain the whole Bessarabia. However, at the end of the First World War, Romania's suzerainty over Dobruja was reestablished. According to the Treaty of Craiova, in September 1940, Romania ceded again Southern Dobruja to Bulgaria. The two countries agreed on a population exchange for the two parts of Dobruja: more than 100,000 Romanians left the Southern part and more than 70,000 Bulgarians left the Northern part. This act seemed to solve the dispute over Dobruja between Romania and Bulgaria.

In 1940 Romania was forced to cede Bessarabia to the Soviet Union. During the Second World War, the Romanian Army reoccupied the province between 1941 and 1944. At the end of the war, the Soviet Union annexed again Bessarabia reorganizing its administration: most of the territory, including the county of Cahul, formed the Soviet Republic of Moldova while some areas from (including the counties of Ismail and Bolgrad) were assigned to the Soviet Republic of Ukraine. In 1948, the Romanian Government ceded to the Soviet Union the Snake Island, with a strategic position on the Danube Mouths. After the dissolution of the Soviet Union, in 1991, both Republic of Moldavia and Ukraine proclaimed their independence. By a treaty signed in 1997, Romania recognized the suzerainty of Ukraine over the territories that belonged to the Southern Bessarabia.

In 1878, it wasn't an easy task for the three Romanian statesmen, Prince Carol, Prime Minister Ion C. Bratianu and the foreign minister Mihail Kogălniceanu, to convince the public opinion to accept the territorial exchange. Based on the later evolutions we could conclude that their pragmatism brought Romania a province with strategic importance.

\section{References}

1. Abramson, S. F., \& Carter, D. B. (2016). The historical origins of territorial disputes. The American Political Science Review, 110(4), 675.

2. Abramson, S. F. (2017). The economic origins of the territorial state. International Organization, 71(1), 97-130.

3. Ardeleanu, C. (2006). Efectele construirii căii ferate Cernavodă-Constanţa asupra navigației dunărene (1859-1860). Analele Universității “Ovidius" Constanța - seria Istoria-Științte Politice-Relații Internationale și Studii Europene, Studii de Securitate (3), 41-54.

4. Ardeleanu, C. (2008). Evoluția intereselor economice si politice britanice la gurile Dunării (1829-1914). Editura Istros, Brăila.

5. Boia, L. (2015). Cum s-a românizat România. Editura Humanitas, București.

6. Boldur, A., V. (1992). Istoria Basarabiei, Editura Victor Frun₹ă, București.

7. Brătianu, G., I. (1995). Basarabia - drepturi naționale şi istorice, Editura Semne, București.

8. Buşă, D., V. (2003). Modificări politico-teritoriale în sud-estul Europei intre Congresul de la Berlin și Primul Război Mondial: (1878-1914), Editura Paideia, Bucurestit. 
9. Buse, C. (1976). Comertul exterior prin Galați sub regimul de port franc: 1837 - 1883. Editura Academiei Republicii Socialiste România, București.

10. Carter, D. B., \& Goemans, H. E. (2011). The making of the territorial order: New borders and the emergence of interstate conflict. International Organization, 65(02), 275-309.

11. Chirtoagă, I. (2004). Târguri şi cetăţi din sud-estul Moldovei: secolul al XIV-lea, inceputul secolului al XIX-lea, Editura Prut International, Chişinău.

12. Ciachir, N. (1992). Basarabia sub stăpânire țaristă : (1812-1917), Editura Didactică şi Pedagogică, București.

13. Ciachir, N. (1996). Marile puteri și România: (1856-1947), Editura Albatros, Bucureşti.

14. Constantin, I. (1995). România, Marile Puteri și problema Basarabiei, Editura Enciclopedică, București.

15. Celik, N. (2010). Black Sea and the Balkans under Ottoman Rule. Karadeniz. Araşttrmalar, (24), 1-27.

16. Damean, S., L. (2011). Romania si Congresul de Pace de la Berlin (1878), Editura Mica Valabie, Bucuresti.

17. Dănescu, G. (1897). Dicţionarul geografic, statistic, economic şi istoric al județului Constanţa, Tipografia şi Fonderia de Litere Thoma Basilescu, Bucurestiti.

18. Duminica, I. (2017). Coloniile bulgarilor in Basarabia (anii 1806-1856) (Doctoral dissertation, CEP USM).

19. Dumitriu R. \& Stefanescu R. (2016). Strategic Decisions on Industrialization: Case of Galati Steel Work, Vanguard Scientific Instruments in Management 12(1).

20. Filipescu, C., \& Giurgea, E. (1919). Basarabia: Consideratiuni generale, agricole, economice şi statistice, Institutul de Arte Grafice „România Nouă”, Chișinău.

21. Forsberg, T. (1996). Explaining territorial disputes: from power politics to normative reasons. Journal of Peace Research, 33(4), 433449.

22. Giurescu, C. C. (1928). Din istoria nonă a Dobrogei, Editura Cartea Românească, București.

23. Goertr, G., \& Diebl, P. (1992). Territorial changes and international conflict. Studies in International Conflict, Volume 5, Routledge, London.

24. Hassner, R. E. (2004). The Path to Indivisibility: Time and the Entrenchment of Territorial Disputes. In Annual Meeting of the American Political Science Association, Chicago, Illinois.

25. Hunt, C. (2013). "Seeing Like a State": Romanian Policies in Northern Dobruca and the Muslims, 18781914. Studia et Documenta Turcologica, 1, 55-86.

26. Ionescu, D., P. (2000). Răð̧boiul de independență a României şi problema Basarabiei, Editura Academiei Române, Bucuresti.

27. Ionescu, M., D. (1904). Dobrogia în pragul veacului al XX-lea: Geografia matematicăa, fisică, politicăa, economică şi militară. Atelierele grafice I. V. Socecu, Bucurestit.

28. Iordacbi, C. (2002). «la Californie des Roumains» L'intégration de la Dobroudja du Nord à la Roumanie, 1878-1913. Balkanologie. Revue d'études pluridisciplinaires, 6(1-2), 167-197.

29. Iordachi, C. (2013). De la o „capcană geopolitică” la „vechi pământ românesc”: integrarea Dobrogei în România, 1878-1913, Archiva Moldaviae, 5, 233-286.

30. Iorga, N. (1899). Studii istorice asupra Chiliei și Cetăți-Albe. Editura Academiei Române, București.

31. Iorga, N. (1916). Politica externă a regelui Carol I: lecții ținute la Universitatea din București, Institutul de Arte Grafice Carol Gobl, București.

32. Jelavich, B. (1969). Russia and the Reacquisition of Southern Bessarabia, 1875-1878, SiidostForschungen 28, 199-237.

33. Kacowicz, A. M. (1994). The problem of peaceful territorial change. International Studies Quarterly, 38(2), 219-254.

34. Kontogeorgis, D. M. (2016). Romanian Danubian and Black Sea Ports during the Nineteenth Century. in Porfyriou, H. \& Sepe, M. (Eds.). Waterfronts Revisited: European Ports in a Historic and Global Perspective, Routledge.

35. Lazarovici, E., B. (1920). Construcția și exploatarea portului Constanța, Analele Dobrogei, 4(1).

36. Markoff, M. G. (1918). Bulgaria's historical rights to Dobrudja. Paul Haupt Akademische Buchhandlung vormals Max Drechsel. 
37. Nélidow, D. (1915). Souvenirs d'avant et d'après la Guerre de 1877-1878. Revue des Deux Mondes (1829-1971), 27(2), 302-339.

38. Nistor, I. (1991). Istoria Basarabiei, Cartea moldovenească, Chişinău.

39. Scurtu, I. (2004). Istoria românilor în timpul celor patru regi (1866 - 1947), Ediția a II-a, revăzută şi adăngită, Volumul I, Carol I, Editura Enciclopedică, București.

40. Starr, H. (2005). Territory, proximity, and spatiality: The geography of international conflict. International Studies Review, 7(3), 387-406.

41. Starr, H., \& Thomas, G. D. (2005). The Nature of Borders and International Conflict: Revisiting Hypotheses on Territory. International Studies Quarterly, 49, 123-139.

42. Tir, J., Schafer, P., Diehl, P. F., \& Goertr, G. (1998). Territorial changes, 1816-1996: Procedures and data. Conflict Management and Peace Science, 16(1), 89-97.

43. Tir, J. (2006). Redrawing the map to promote peace: territorial dispute management via territorial changes. Lexington Books.

44. Turcanu, I. (2009). Câteva observații asupra numelui Basarabia. Revista ISTROS, 15(1), 233-249.

45. Turcanu, I. (2011). Descrierea Basarabiei: teritoriul dintre Prut și Nistru în evoluție istorică (din primele secole ale mileniului II până la sfirșitul secolului al XX-lea). Editura Cartier, Chişinău. 